\title{
Communication
}

\section{Negotiation by proxy: a proposal ${ }^{1}$}

\section{J. DAVID SINGER \\ Department of Political Science and Mental Health Research Institute, The University of Michigan}

Although it remains to be demonstrated empirically, the general impression among students of diplomatic history and international relations is that the fruitfulness of inter-nation negotiation as a conflict-resolving technique has tended to diminish as political participation of the masses has increased. If this proposition is essentially correct, it behooves us-given the increasing costs of diplomatic failure-to look for an explanation in the relationship between the negotiators and the national societies from which they come.

The negotiator or diplomat is unlikely to get much in the way of either reward or punishment from his opposite number across the bargaining table, but his own society can grant or withhold a great many of the perquisites and values which he may desire. And because there will almost always be, in any large national society, some group or faction which thinks it can benefit from

\footnotetext{
1 This memorandum was originally written in 1962 , but several readers felt it was based on too pessimistic an interpretation of modern diplomacy. Hence it was filed away, only to be resurrected by the unhappy events of the period since then. Though one of the original critics (Inis L. Claude) would still quarrel with the diagnosis, and a recent reader (Bruce Russett) is uncertain about the prescription, the consensus is that its publication might be heuristically useful.
}

failure in negotiations and a continuation of the unmitigated conflict, the negotiator is always vulnerable to attack from such quarters if he is successful. That is, in order to be successful (assuming approximate power equality between the two nations), the negotiator for nation A must "give away" something in the way of concessions to his opposite number from nation B. As a consequence, the "no peace" (or "peace on our terms only") faction in nation A will easily be able to accuse the negotiator -or the political party or administration which he represents - of having "sold out" or "surrendered." Is there any conceivable exit from such a dilemma? To put it another way, is there any means by which we might partially depoliticize (in the domestic sense) diplomatic negotiations? Several analogous situations come to mind, and from them we might conceivably draw some useful suggestions.

One technique, already well-established in international relations, is the use of the mediator. In this case a more or less disinterested third party participates in the bargaining sessions or else acts as a gobetween, meeting with each of the nation's representatives independently. In either event, some group of nationals representing their own government is bargaining with another group of nationals representing the 
other side. Thus, despite the theoretically improved probability of the success of the mediator, historical evidence suggests that this technique has been only slightly more successful than that of face-to-face confrontation. Is there a way to move the negotiators further from the pressures and considerations which inhibit their search for "businesslike" solutions?

One alternative comes to mind which might be worthy of further analysis. Let there be established, in a large number of countries, a new type of law firm, whose primary purpose is the representation of nations which are or might become involved in a particular dispute. These firms would be, in a sense, professional bargainers "for hire" to national governments. Once a government had selected a particular firm (preferably from a "disinterested" nation) to represent it in a particular round of negotiation, the following procedure might be applied.

In a very private and quiet meeting, the responsible political officials of the nation would provide their hired bargainers (or mercenaries) with this information:

(1) The most desirable outcome that could be imagined, from their point of view.

(2) The minimum price, in the form of concessions, which they are willing to pay for any particular concession from the other side.

(3) The expected price necessary in order to get such a concession.

(4) The maximum price they would pay to get that concession.

(5) The least desirable outcome, short of no agreement at all.

In addition to providing the bargaining firm with one's minimal, optimal, and maximal outcome preferences, certain other rules need to be articulated. Among the more important are the fee scales. If we accept the argument that one of the main inhibitors to successful negotiation between diplomats is the balance of incentives and disincentives, we can appreciate the importance of the monetary fees involved here. The important thing is to provide the bargainers with a very high incentive to negotiate a successful agreement, and at the same time to provide almost as high an incentive for striking a very hard bargain.

One way to meet these two needs is to stipulate that a very minimal fee will be paid if a formal agreement has not been reached in a specific period of time; this minimal fee might be more or less equivalent to the cost involved for the law firm in preparing for the negotiations, plus a nominal overhead charge. Under such conditions, firms that are not successful in negotiating agreements will be able to remain in business, but will never get rich! On the other hand, if an agreement is reached, let the firm be paid something on the order of three to six times their basic cost of preparation. And on top of this, the national representatives and their lawyers would negotiate a fairly detailed set of "contingency fees." Under such an arrangement, the firm would be given an additional increment depending on the number and extent of the concessions which they end up making in exchange for the desired concessions from the other nation's firm. Such a contractual arrangement would generate a very high incentive both to conclude an agreement and to strike the hardest possible bargain; it is, of course, essential that the bargaining firm have no incentive to "give anything away."

Of course this scheme could be sabotaged by fee-splitting or side payments; one firm could make a great many concessions to the other and collect its relatively modest fee, but supplement that with a prearranged 
share of the very large fee collected by the other firm, which had struck a highly successful bargain from its client's point of view. This kind of collusion would, however, be inhibited by the same factor which impinges on all professionals: the realization that one such episode would destroy the firm's reputation. Moreover, if the negotiation-by-proxy arrangement were to be part of an overall modification of conflict management techniques, including compulsory arbitration and compulsory adjudication, the incentives for honest bargaining would be increased. That is, unless one side's firm felt its position to be extremely weak, it would prefer to break off the negotiations and trust to third-party intervention than to submit to the equivalent of bribery and collusion.

Though this set of procedures may sound highly unorthodox, one should bear in mind that it is not basically different from certain activities in which law firms are already involved. First of all, in a great many potential litigations, the adversaries empower their attorneys to try to negotiate an "out of court settlement." Secondly, in some union contract negotiations-in the United States at least-both labor and management engage law firms to bargain with each other. In these cases the actual adversaries do not necessarily encounter one another in a face-to-face situation; rather, each side is represented by a group of professional, disinterested experts. Not only do such arrangements reduce the intrusion of inhibiting and extraneous considerations like ideology, personal antipathy, and (occasionally) downright incompetence, but they alsoand this is the main point-permit the bargaining to take place between parties which stand to gain, rather than lose, from a successfully negotiated agreement.

Now it may be argued that the foreign ministry officials who instruct and bargain with their lawyers are, despite the attempted deception, still engaged in concession-making; therefore they would still be vulnerable to, and inhibited by, domestic criticism. Certainly there is no way around the fact that elected or appointed policy-makers must always, one way or another, be the ones to decide what the appropriate quid pro quo should be. But if these decisions were made in professional privacy and were more or less irrevocable during the bargaining period, many of those extraneous and irrelevant factors which regularly debilitate the normal diplomatic process could be reduced or eliminated.

It might also be charged that this would represent a serious departure from democratic procedures, and in a limited and literal sense this is correct. On the other hand, it is still up to the elected government to make the crucial policy decisions and to ascertain the acceptable payoffs; the next election can never be too far from their minds. The lawyers merely carry out instructions, albeit complicated and contingent instructions. As a matter of fact, by being compelled to spell out for these lawyers its bargaining rules and preferences, any government would be much more likely to reflect the national interest than under present conditions, where "seat-of-the-pants" hunches and pressure-group tactics lead frequently to highly irrational bargaining positions. Furthermore, there always remains the opportunity for rejection during the ratification process.

At least two alternative ratification arrangements come to mind. In one case the national governments might stipulate that, once the formal agreement is reached by their attorneys, it would still have to be approved and ratified by their own appropriate legislative and administrative proc- 
esses. This procedure would most likely be the one insisted upon while the practice was being tested. But if it did turn out to be a successful approach to the postulated dilemma in negotiation, it is quite possible that governments and electorates would be willing, in a sense, to give their bargaining firms the "power of attorney." In such an event, the agreement reached would become binding merely on the countersignature of the foreign ministers or heads of state, signifying that the attorneys had faithfully adhered to the rules and stipulations.

Needless to say, there are a great many difficulties, small and large, which need to be thought through before a procedure such as that outlined above could ever be adopted by national governments. But as government has become increasingly susceptible to the caprices of public opinion and partisan efforts to exploit such opinion, diplomacy seems to have become less and less successful. The major powers thus find it nearly impossible to negotiate either on important political conflicts or on arrangements for the gradual reduction of national military capabilities. While this dismal record continues, the likelihood of nuclear war will probably increase. Given such an unpleasant prospect, a somewhat off-beat method of negotiation may warrant more serious attention than it would in less dangerous times. 